\section{Alpha thalassemia among sickle cell anaemia patients in Kampala, Uganda}

Irene Lubega, Christopher M Ndugwa, Edison A Mworozi, James K Tumwine

Makerere University College of Health Sciences, Paediatrics and Child Health

\section{Abstract:}

Background: Sickle cell anaemia is prevalent in sub Saharan Africa. While $\alpha+$-thalassaemia is known to modulate sickle cell anaemia, its magnitude and significance in Uganda have hitherto not been described.

Objectives: To determine the prevalence of $\alpha+$ thalassaemia among sickle cell anaemia patients in Mulago Hospital and to describe the clinical and laboratory findings in these patients.

Methods: A cross sectional study was carried out on patients with sickle cell anaemia in Kampala. Dried blood spots were used to analyze for the deletional $\alpha+$ thalassaemia using multiplex polymerase chain reaction.

Results: Of the 142 patients with sickle cell anaemia, $110(77.5 \%)$ had the $\alpha \alpha+$ thalassaemia deletion. The gene frequency of $(-\alpha)$ was 0.425 . Ninety one percent $(100 / 110)$ of those with $\alpha+$ thalassaemia were heterozygous $(\alpha \alpha / \alpha-)$. Amongst the patients older than 60 months, $15(83.3 \%)$ of those without $\alpha \alpha+$ thalassaemia had significant hepatomegaly of greater than $4 \mathrm{~cm}$ compared to $36(45.6 \%)$ of those with $\alpha+$ thalassaemia ( $\mathrm{p}=0.003)$.

Conclusion: The gene frequency of $(-\alpha)$ of 0.425 noted in this study is higher than that reported from many places in Africa. Concurrent alpha thalassemia might be a protective trait against significant hepatomegaly in sickle cell anaemia patients more than 60 months of age at Mulago hospital.

Keywords: Alpha thalassemia, sickle cell anaemia patients, Kampala, Uganda

DOI: http://dx.doi.org/10.4314/ahs.v15i2.48

Introduction $\quad$ features of SCA ${ }^{6-8}$. It is widespread in Africa and is (SCA) as well as those with mild disease were reported malaria ${ }^{9-12}$. While there have been reports of $\alpha+-$ thalin Jamaica ${ }^{1}$.

Various factors, both genetic and environmental, are mation on its prevalence and interaction with sickle cell known to influence the clinical course and survival of anaemia in Uganda ${ }^{13-15}$.

patients with SCA. These factors do not only include

the different haplotypes of sickle cell and infections, In 1958 Raper described nine cases of thalassaemia but also the interaction of sickle cell with alpha thalas- major amongst Ugandans of Indian origin ${ }^{16}$. The main saemia.

About $30 \%$ of patients with SCA have concurrent deletional alpha thalassaemia $(\alpha+\text {-thalassaemia })^{2}$. The heterozygotes have reduced concentration of $\mathrm{HbS}$, and HbS polymerization, less haemolysis, higher PCV, lower $\mathrm{MCV}$ and lower reticulocyte counts ${ }^{3-5}$. Alpha thalassaemia tends to ameliorate some but not all of the clinical

\section{Corresponding author:}

Irene Lubega

Makerere University College

of Health Sciences, Paediatrics and Child Health

Email: ilubega@mujhu.org prevalence of $\alpha+$-thalassaemia among SCA patients attending the sickle cell clinic at Mulago national referra hospital Kampala, using multiplex polymerase chain reaction (MPCR), and to describe laboratory and clinical findings in these patients. This paper describes select clinical, and laboratory characteristics of a cross-section of children with SCA.

\section{Methods}

The Sickle Cell Clinic at Mulago hospital has over 7000 registered patients with SCA. This cross sectional study was conducted from December 1994 to January 1995.

\section{Sampling and recruitment}

Assuming a prevalence of $\alpha+$-thalassaemia of 0.26 based on a Kenyan study(15) and a precision of $6.3 \%$ at $95 \%$ confidence intervals, every third patient with a

confirmed diagnosis of SCA, was enrolled and data was obtained from 142 children aged up to 19 years.

Basic demographic, anthropometric, and clinical data were collected. Those who were very sick and those who had had a blood transfusion in the previous three months were excluded.

Written informed consent was obtained from the parent or caretaker of each child, and ethical clearance was

obtained from the Department of Paediatrics and Child Health, Makerere University and the National Council of Science and Technology.

\section{Laboratory data}

Haematological data was obtained for all children using a haematology analyser (Beckman Coulter Inc, AcT Miami FL 33196-2500 USA). Haemoglobin was analysed by electrophoresis on cellulose acetate gels (Helena Laboratories UK limited) at pH8.6 voltage $200 \mathrm{v}$. Milabeled using serum as a marker. Dried blood spots for the DNA analysis were kept at a room temperature for at least four hours, stored at $4^{\circ} \mathrm{C}$ and later transported to the Clinical Biochemistry Laboratory - Evanston Hospital USA, where DNA analysis to type for $\alpha$-globin genotype was performed using Multiplex Polymerase Chain Reaction (MPCR) techniques ${ }^{17}$. ia parasites and peripheral blood picture and were performed on all study participants. gration time was at least 30 minutes, and the strips were

Thick and thin blood smears were analysed for malar-

Data management and statistical analysis Epi-info software version 6 was used for data-entry and nalysis. The sample was described using frequency distributions, while tables and graphs were used to illustrate variables.

Mean values for continuous variables were reported as \pm 2 standards deviations.

The chi squared test was used to determine associations between 'exposure' and the main outcome variables.

Results

A total of 142 patients with SCA were recruited of whom $67(47.2 \%)$ were males.

Alpha -thalassaemia status

The gene frequency for (-oc) deletion was 0.425.One hundred and ten participants $(77.5 \%)$ had $\alpha+$ thalassaemia, while 32 participants $(22.5 \%)$ had a normal component of alpha genes. Of the 110 participants with $\alpha+$ thalassaemia, $100(90.9 \%$ ) were heterozygotes (ococ/ oc-) while $10(9.0 \%)$ were homozygotes (oc-/oc-). The majority of the participants with $\alpha+$ thalassaemia were in the age group 61-120 months. Among participants who were more than 120 months the majority $44 / 55$ $80 \%$ ) were from the $\alpha+$ thalassaemia group.

The Baganda were the predominant ethnic group accounting for $76.1 \%$ (108/142), followed by the Basoga with $8.5 \% .(12 / 142)$.

The age range of the participants was 5.9 months to 19 years, with a mean age of 8.7 years and a median of 8.2 years. The age group 61-120 months, had the largest number of study participants ( $n=43)$. Fig 1

Figure 1. Age distribution by $\alpha^{+}$thalassaemia ( $\alpha^{+}$thal) status

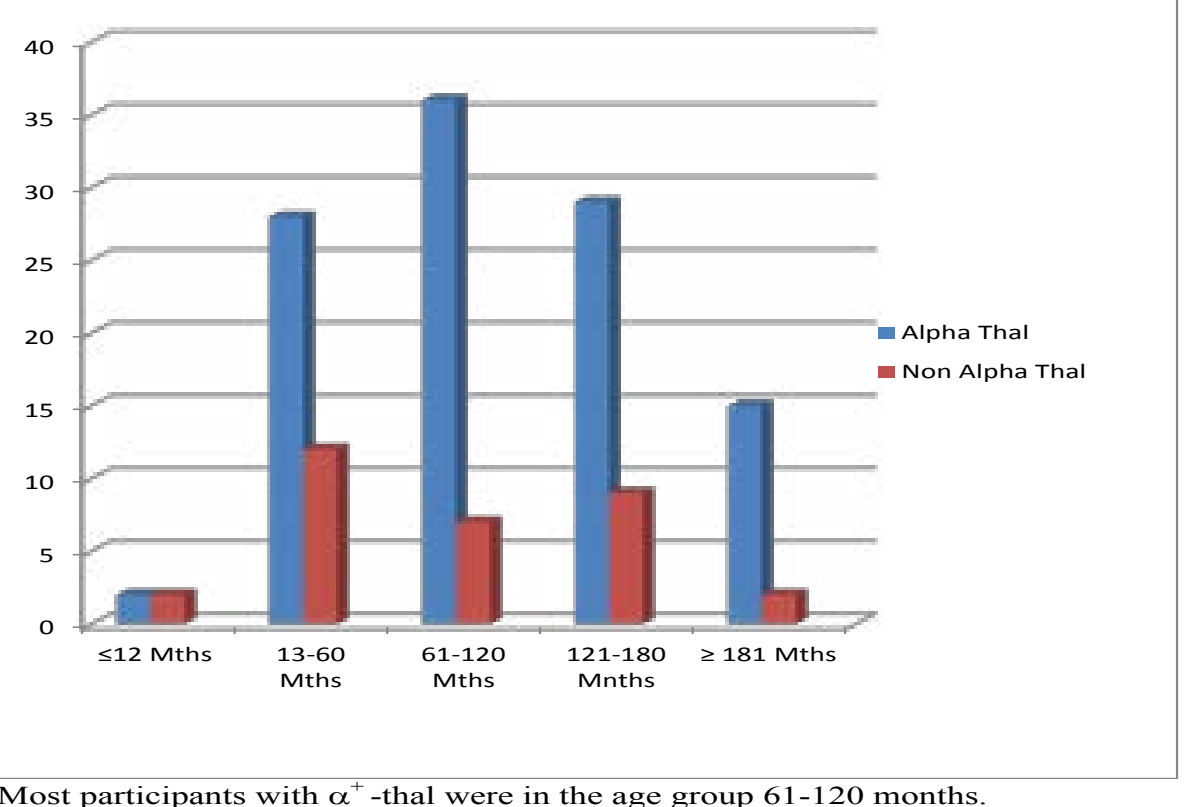


Age at initial diagnosis

Figure 2 shows the relationship between age at initial

the age of 5 years, and by the age of five years $79 \%$ had diagnosis of SCA and $\alpha+$ thalassaemia status.

osis of SCA made. Participants were grouped according to age at which a which a diagnosis of SCA was first made $(\mathrm{P}=0.39)$. diagnosis of sickle cell anemia was first made. In about Of the 110 participants with $\alpha+$ thalassaemia, 26 half the cases $((51.4 \%)(73 / 142))$, the disease present- $(23.6 \%)$ had the diagnosis of SCA made after 5 years ed during the first 12 months of life, with only $21 \%$ in comparison to only $4(12.5 \%$ in the non- $\alpha+$ thalas$(30 / 142)$ of all the participants first presenting after saemia group.

\section{Fig 2. Disnibution of Patients by Age at First Dingnosis and alpha-} thal Status

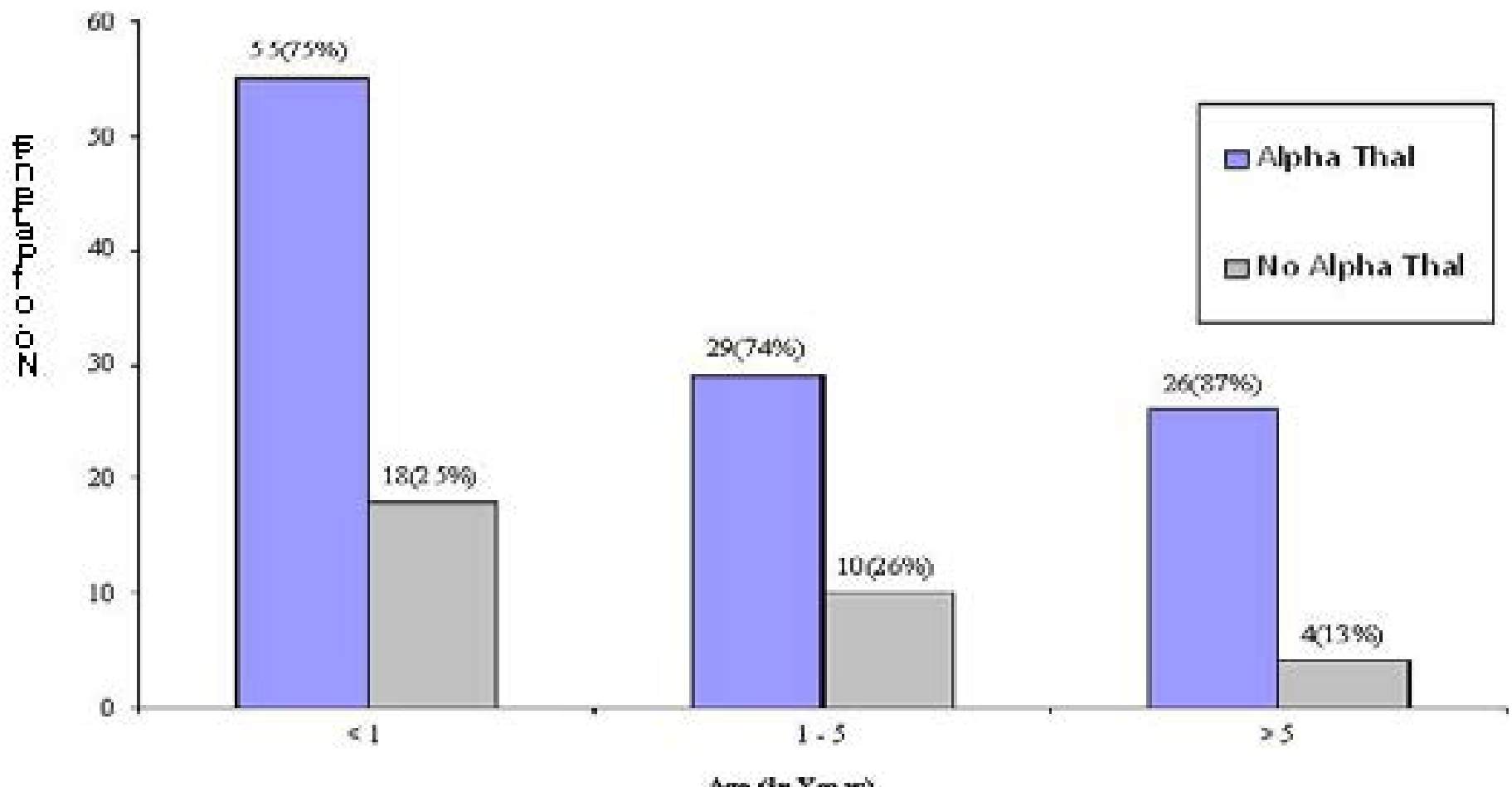

Clinical history and physical findings of the participants 107 (75.3\%) of all the participants had had a duration is presented in Table 1 and 2 . At the time of the study, of symptoms of SCA for less than 1 year.

\begin{tabular}{|c|c|c|c|c|}
\hline History/Symptom & $\alpha^{+}$thal $(n=110)$ & $\begin{array}{l}\text { Non- } \alpha^{+} \text {thal } \\
(\mathrm{n}=32)\end{array}$ & $P$ value & OR (CI) \\
\hline $\begin{array}{l}\text { Hand and foot } \\
\text { syndrome at initial } \\
\text { presentation }\end{array}$ & $69(65.7 \%)$ & $21(65.6 \%)$ & 0.75 & $0.88(0.36-2.16)$ \\
\hline $\begin{array}{l}\text { Severe anaemia at } \\
\text { Initial presentation }\end{array}$ & $14(13.3 \%)$ & $6(18.8 \%)$ & 0.39 & $0.63(0.20-2.06)$ \\
\hline $\begin{array}{l}\text { Hand foot } \\
\text { syndrome in } \\
\text { The last one year }\end{array}$ & $28(25.7 \%)$ & $10(31.2 \%)$ & 0.52 & $0.75(0.29-1.94)$ \\
\hline $\begin{array}{l}\text { Painful limbs in } \\
\text { the last one year }\end{array}$ & $101(92.7 \%)$ & $26(81.3 \%)$ & 0.087 & $2.59(0.74-8.94)$ \\
\hline $\begin{array}{l}\text { History of } \\
\text { hospitalisation }\end{array}$ & $84(76.4 \%)$ & $26(81.2 \%)$ & 0.56 & $0.75(0.24-2.18)$ \\
\hline Blood transfusion & $49(44.5 \%)$ & $18(56.2 \%)$ & 0.24 & $0.62(0.26-1.48)$ \\
\hline
\end{tabular}

$\mathrm{OR}=$ Odds Ratio $\quad \mathrm{CI}=$ Confidence Intervals
Table 2:

Findings on physical examination of sickle cell patients and $\alpha$ thalassaemia ( $\alpha$ thal)$$
\text { status }
$$

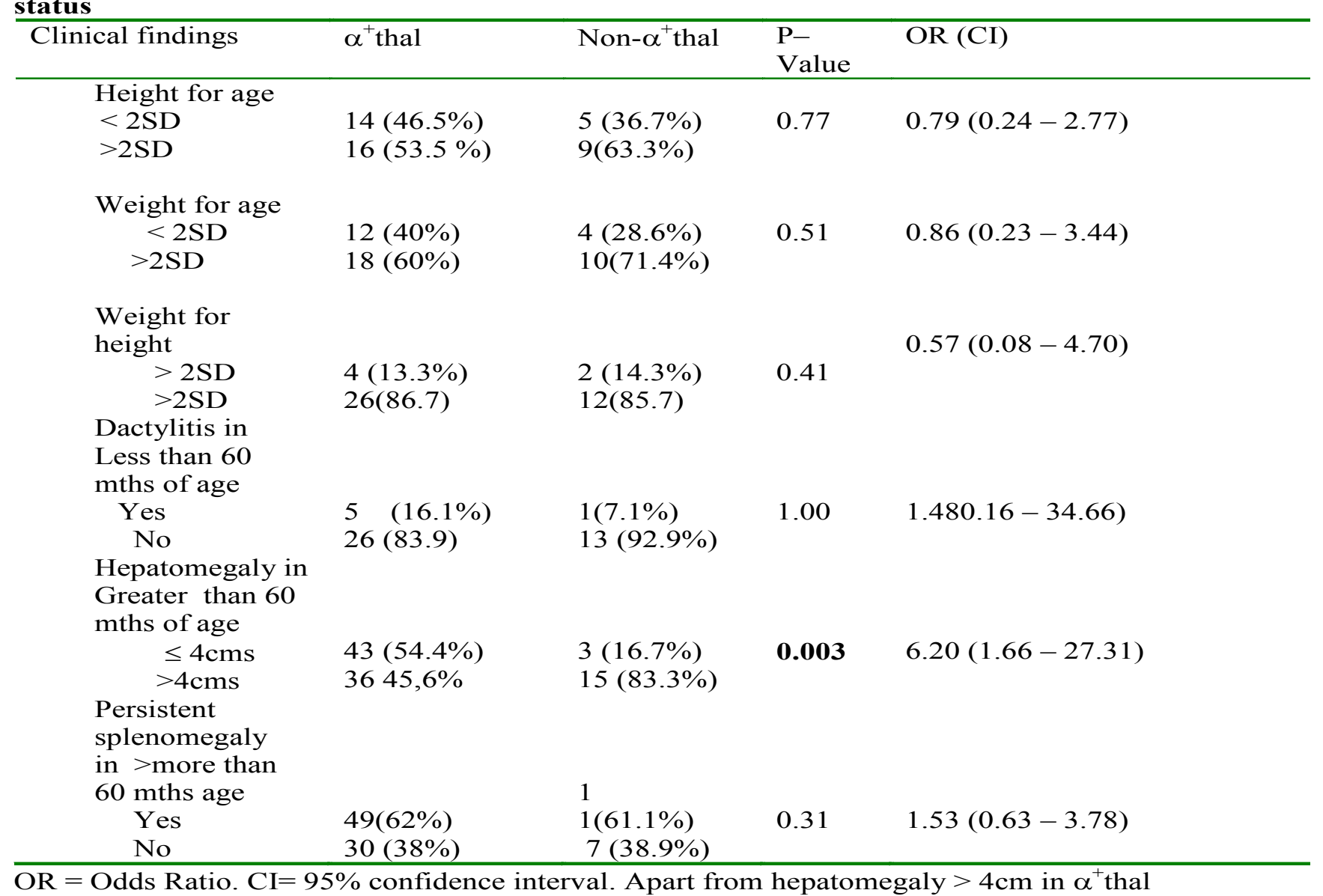

subjects more than 60 months of age, $\alpha^{+}$thal status did not influence the physical findings.

A history of leg ulceration was available in only 3 par- mia groups with $62 \%(49 / 79)$ and $61.1 \%(11 / 18)$ in the ticipants (ages 12,16 and 17 years) and only 1 partici- $\alpha+$ thalassaemia and non- $\alpha+$ thalassaemia group respecpant (from the non- $\alpha+$ thalassaemia) was found to have tively $(P=0.94)$.

chronic leg ulceration.

About half of the participants $55.4 \%(61 / 110)$ in Virtually all participants $((99.3 \%)(141 / 142))$ had a hethe $\alpha+$ thalassaemia group and $43.7 \%(14 / 32)$ in the patomegaly $(1-15 \mathrm{~cm})$. Amongst the participants oldnon- $\alpha+$ thalassaemia group had no history of blood er than 60 months, $83.3 \%$ (15) of those without the transfusion. $\quad \alpha+$ thalassaemia deletion had a hepatomegaly of greater More than half the patients $55.6 \%(79 / 142)$ had no than $4 \mathrm{~cm}$ compared to $45.6 \%$ (36) of those with the palpable spleen and the frequency of persistent sple- $\alpha+$ thalassaemia $(p=0.003)$. Table 2

nomegaly in patients above the age of 60 months was The haematological indices did not differ between the similar in both $\alpha+$ thalassaemia and non- $\alpha+$ thalassae- two groups. Table 3 
Haematological findings amongst sickle cell anaemia and $\alpha^{+}$thalassaemia ( $\alpha^{+}$thal) ststus.

\begin{tabular}{llll}
\hline $\begin{array}{l}\text { Haematological } \\
\text { variables(mean) }\end{array}$ & $\alpha^{+}$thal & Non- $\alpha^{+}$thal & P-value \\
\hline (a) $\mathrm{Hb} \mathrm{gdl}^{-1}$ & 7.24 & 7.25 & 0.937 \\
(b) $\mathrm{Rbc} \times 101^{-1}$ & 2.54 & 2.50 & 0.933 \\
(c) $\mathrm{PCV}(\%)$ & 23.17 & 22.95 & 0.714 \\
(d) $\mathrm{MCV}(\mathrm{fl})$ & 91.44 & 91.41 & 0.616 \\
(e) $\mathrm{MCH}(\mathrm{pg})$ & 29.88 & 29.50 & 0.845 \\
(f) $\mathrm{MCHC}\left(\mathrm{gdl}^{-1}\right)$ & 32.71 & 31.96 & 0.448 \\
\hline
\end{tabular}

$\alpha^{+}$thal status did not influence the haematological indices.

Only $20(14.3 \%)$ of 140 participants had malarial par- that recorded by Williams et al on the Kenyan coast ${ }^{12,20}$. asites detected in their blood. All of them had Plas- Other studies including those of Ojwang et al in Kenya modium falciprarum 1-10 parasites per 100 thick film and Falusi et al in Nigeria have recorded frequencies of fields. Other than Plasmodium falciprarum no other 0.26 and 0.24 respectively ${ }^{15,21}$

malaria parasites were detected and only 3 of these par-

ticipants were free of any symptoms at the time. The high $(-\alpha)$ gene frequency in the current study commented was hypochromia with poikilocytosis and in all suggestion by other investigators including Moule that participants, sickle cells were detected. Sixty three par- there seems to be a gradient for the $(-\alpha)$ across Africa, ticipants $(44.4 \%)$ had marked hypochromia, $64(45.0 \%)$ the gene frequency being highest in equatorial Africa had moderate hypocromia, while $14(9.8 \%)$ had mild and lowest in both Northern and Southern Africa ${ }^{12}$. hypochromia. Only one patient was reported to have a normocytic peripheral blood picture.

\section{Discussion}

The Baganda were the predominant ethnic group 76.1\% $(108 / 142)$ reflecting the general ethnic composition of patients attending clinics and general wards in Mulago hospital. Ndugwa and Kanyike in their analysis of patient's attendance in the same sickle cell clinic reported a similar percentage of $81 \%{ }^{18}$. The Baganda have been previously reported to have a high incidence of SCA with a carrier rate of $17 \% .^{19}$

A gene frequency of $(-\alpha)$ of 0.425 recorded in this study is probably one of the highest gene frequencies recorded in sub Saharan Africa and comparable to that attributed to the method used to detect the $\alpha+$ thalassaemia deletion. Unlike the MPCR technique used in the current study ${ }^{17}$, earlier tests were based on imprecise globin synthesis techniques that they could not clearly differentiate between $\alpha+$ thalassaemia homozygotes, heterozygotes and normal individuals ${ }^{22,23}$. The question that inevitably arises is that of the gene frequency in the general population versus that in patients with SCA. Does the $\mathrm{HbS}$ gene have an affinity for $\alpha+$-thalassaemia and will the frequency of $\alpha+$-thalassaemia be higher among patients with SCA than in the general population? SCA individuals $(-\alpha=0.1)$ whilst in Benin, and Upper years $(112 / 142(78.9 \%)$ had symptoms of SCA.
Volta the gene frequency in HbSS individuals of 0.27 was almost twice the gene frequency in the non SCA individuals $(0.14)^{24 .}$ In Congo Brazzaville it was noted that the gene frequency for the deletional $-\mathrm{oc}^{3.7}$ was $0.40,0.36,0.44$ and 0.45 in newborns, non-SCA adults, sickle trait and individuals with SCA respectively ${ }^{12}$

To investigate whether $\alpha+$ thalassaemia status influences age at initial presentation of symptoms of SCA, we used "age at initial diagnosis" as a surrogate marker in the analysis. In spite of this approximation and knowing well that there may have been a variable sequential gap between first symptoms and when a diagnosis of SCA was made, it is noteworthy that by 1 year about half of the participants $((73 / 142)(51.4 \%))$, and by 5

Although half of the patients presented with symptoms of SCA during infancy, there were only 4 patients with SCA below one year in this study. After infancy, the overall number of patients rose sharply up to 10 years. These results are comparable to those of an observational study among SCA children in Kenya ${ }^{25}$ That many children die in infancy before a diagnosis of SCA is made and that the older ones that are seen are a reflection of those who have favorable genetic or environmental factors for survival beyond infancy, might explain this trend.

There were fewer participants over the age of 10 years. It was observed that for the patients who were more than 15 years of age, the proportion of individuals with $\alpha+$ thalassaemia was greater than that of SCA individuals without $\alpha+$ thalassaemia. Whether the presence of $\alpha+$ thalassaemia improves survival in SCA patients is not certain.

There was no statistically significant correlation between $\alpha+$ thalassaemia status and a history of painful $\mathrm{mbs}$ in the last one year, and a history or presence of or leg ulceration was virtually missing in this population of SCA patients and so were Vaso-occlusive events that are highly dependent on PCV, such as stroke.

\section{Acknowledgements}

We thank the patients and staff of the sickle cell clinic at Mulago hospital, Professor Peter J. Ojwang, University of Nairobi, for their help in this study and the Nuffield foundation and the German Academic Exchange Service (DAAD) scholarship for their financial assistance.

\section{References}

1. Serjeant GR, Richards R, Barbor PR, Milner PF Relatively benign sickle-cell anaemia in 60 patient aged over 30 in the West Indies. British Medical Journal. 1968;3(5610):86-91. Epub 1968/07/13.

2. Steinberg MH, Embury SH. Alpha-thalassemia in blacks: genetic and clinical aspects and interactions with the sickle hemoglobin gene. Blood. 1986;68(5):985 PubMed -90. Epub 1986/11/01.

3. de Ceulaer K, Higgs DR, Weatherall DJ, Hayes RJ, Serjeant BE, Serjeant GR. alpha-Thalassemia reduces the hemolytic rate in homozygous sickle-cell disease. The New England Journal of Medicine. 1983;309(3):189-90. Epub 1983/07/21.

4. Embury SH, Clark MR, Monroy G, Mohandas N. Concurrent sickle cell anemia and alpha-thalassemia. Effect on pathological properties of sickle erythrocytes. The Journal of Clinical Investigation. 1984;73(1):116-23. Epub 1984/01/01.

5. Higgs DR, Aldridge BE, Lamb J, Clegg JB, WeathThere have been several studies on the effect of $\alpha+$ thal- erall DJ, Hayes RJ, et al. The interaction of alpha-thalassaemia on survival of patients with SCA but the re- assemia and homozygous sickle-cell disease. The Nen sults are not cosmopolitan. Mears et al has suggested England Journal of Medicine. 1982;306(24):1441-6. Epub that $\alpha+$ thalassaemia is related to prolonged survival 1982/06/17.

while Higgs, Miller and Mouele ${ }^{5,12,26,27}$ did not make the 6. Steinberg MH. Predicting clinical severity in sickle cell same conclusions. This lack of precision could be partly anaemia. British Journal of Haematology. 2005;129(4):465due to the small number of patients studied as well as 81. Epub 2005/05/10.

honsystematic and structured collection of clinical data 7. van Enk A, Lang A, White JM, Lehmann H. Benign in the different studies. In order to settle this question obstetric history in women withsickle-cell anaemia

one would have to study a large group of patients with associated with -thalassaemia. British Medical Journal. SCA in the ber of those with and without $\alpha+$ thalassaemia but this would have to be done after controlling for other genetic and environmental factors that profoundly affect child survival 1972;4(5839):524-6. Epub 1972/12/02.

8. Braden DS, Covitz W, Milner PF. Cardiovascular function during rest and exercise in patients with American Journal of Hematology. 1996;52(2):96-102. Epub 1996/06/01. sickle-cell anemia and coexisting alpha thalassemia-2. 
9. Enevold A AM, Sanchez JJ , Carneiro I, Roper C,Børsting C, Lusingu J VL, Lemnge MM,4 Niels Morling N, Riley E and Drakeley CJ. Associations between a+-Thalassemia and Plasmodium falciparum Malarial Infection in Northeastern Tanzania The Journal of Infectious Diseases. 2007;196:451-9.

10. Higgs DR, Pressley L, Clegg JB, Weatherall DJ, Serjeant GR. alpha thalassemia in black populations. The Johns Hopkins Medical Journal. 1980;146(6):300-10. Epub 1980/06/01

11. Dozy AM, Kan YW, Embury SH, Mentzer WC, Wang WC, Lubin B, et al. alpha-Globin gene organisation in blacks precludes the severe form of alpha-thalassaemia. Nature. 1979;280(5723):605-7. Epub 1979/08/16

12. Mouele R, Pambou O, Feingold J, Galacteros F. alpha-thalassemia in Bantu population from Congo-Brazzaville: its interaction with sickle cell anemia. Human heredity. 2000;50(2):118-25. Epub 2000/05/09.

13. Henni T, Bachir D, Tabone P, Jurdic P, Godet J, Colonna P. Hemoglobin Bart's in Northern Algeria. Acta Haematologica. 1981;65(4):240 PubMed -6. Epub 1981/01/01

14. Muklwala EC, Banda J, Siziya S, Atenyi J, Fleming AF, Higgs DR. Alpha thalassaemia in Zambian newborn. Clinical and Laboratory Haematology. 1989;11(1):16. Epub 1989/01/01

15. Ojwang PJ, Ogada T, Beris P, Hattori Y, Lanclos $\mathrm{KD}$, Kutlar A, et al. Haplotypes and alpha globin gene analyses in sickle cell anaemia patients from Kenya. British Journal of Haematology. 1987;65(2):211-5. Epub 1987/02/01.

16. Raper AB. Thalassaemia in families of Indian origin. East African Medical Journal. 1958;35(4):161-70. Epub 1958/04/01.

17. Bowie LJ, Reddy PL, Nagabhushan M, Sevigny P. Detection of alpha-thalassemias by multiplex polymerase chain reaction. Clinical Chemistry. 1994;40(12):2260 PubMed -6. Epub 1994/12/01.

18. Ndugwa CM, Kanyike FB. Analysis of patients attending sickle cell anaemia clinic, New Mulago Hospital, 1970-1971. East African Medical Journal. 1973;50(4):18998.Epub 1973/04/01

19. Lehmann H, Raper AB. Distribution of the sickle-cell trait in Uganda, and its ethnological significance. Nature. 1949;164(4168):494 PubMed. Epub $1949 / 09 / 17$

20. Williams TN WS, Uyoga S, et al. . Both heterozygous and homozygous alpha+ thalassemias protect against severe and fatal Plasmodium falciparum malaria on the coast of Kenya. . Blood. 2005;106 368-71.
1. Falusi AG, Esan GJ, Ayyub H, Higgs DR. Alpha-thalease. European Journal of Haematology. 1987;38(4):370-5. Epub 1987/04/01.

22. Honig G.R Koshy MM, R.G Vida, L.N. Sickle cell syndromes. II. The sickle cell anemia-alpha-thalassemia syndrome. The Journal of Pediatrics. 1978:556-61.

23. Felice AE, Webber B, Miller A, Mayson SM, Harris HF, Henson JB, et al. The association of sickle cell anemia with heterozygous and homozygous alpha-thalassemia-2: in vitro HB chain synthesis. American Journal of Hematology. 1979;6(2):91-106. Epub 1979/01/01.

24. Pagnier J, Dunda-Belkhodja O, Zohoun I, Teyssier J, Baya $H$, Jaeger $G$, et al. $\alpha$-Thalassemia among sickle cell anemia patients in various African populations. 1984. 25. Manish Sadarangani JM, Albert N. Komba TA-A, Charles R. Newton KMa, Williams TN. An observational study of children with sickle cell disease in Kilifi, Kenya. British Journal of Haematology. Volume 146( Issue 6): 675-82

26. Mears JG, Lachman HM, Labie D, Nagel RL. Alpha-thalassemia is related to prolonged survival in sickle cell anemia. Blood. 1983;62(2):286-90

27. Miller ST, Sleeper LA, Pegelow CH, Enos LE, Wang WC, Weiner SJ, et al. Prediction of adverse outcomes in children with sickle cell disease. The New England Journal of Medicine. 2000;342(2):83-9. Epub 2000/01/13.

28. Miller ST, Rieder RF, Rao SP, Brown AK. Cerebrovascular accidents in children with sickle-cell disease and alpha-thalassemia. The Journal of Pediatrics. 1988;113(5):847-9. Epub 1988/11/01.

29. Adekile AD,Tuli M, Haider MZ, Al-Zaabi K, Mohannadi S, Owunwanne A. Influence of alpha-thalassemia trait on spleen function in sickle cell anemia patients with high HbF. American Journal of Hematology. 1996;53(1):1-5. Epub 1996/09/01

30. Wali YA, Al-Lamki Z, Hussein SS, Bererhi H, Kumar D, Wasifuddin S, et al. Splenic function in Oman children with sickle cell disease: correlation with severity index, hemoglobin phenotype, iron status, and alpha-thalassemia trait. Pediatric Hematology and Oncology. 2002;19(7):491-500. Epub 2002/09/10

31. Hsu LL, Miller ST, Wright E, Kutlar A, McKie V, Wang W, et al. Alpha Thalassemia is associated with decreased risk of abnormal transcranial Doppler ultrasonography in children with sickle cell anemia. Journal of Pediatric Hematology/Oncology. 2003;25(8):622-8. Epub 2003/08/07.

32. Belisario AR, Rodrigues CV, Martins ML, Silva CM Viana MB. Coinheritance of alpha-thalassemia decreas- es the risk of cerebrovascular disease in a cohort of children with sickle cell anemia. Hemoglobin. 2010;34(6):516 PubMed -29. Epub 2010/11/17.

33. Koshy M, Entsuah R, Koranda A, Kraus AP, Johnson R, Bellvue R, et al. Leg ulcers in patients with sickle cell disease. Blood. 1989;74(4):1403 PubMed -8. Epub 1989/09/01

34. Platt OS, Thorington BD, Brambilla DJ, Milner PF, Rosse WF, Vichinsky E, et al. Pain in sickle cell disease. Rates and risk factors. The New England Journal of Medicine. 1991;325(1):11-6. Epub 1991/07/04.

35. Billett HH, Nagel RL, Fabry ME. Paradoxical in crease of painful crises in sickle cell patients with alpha-thalassemia. Blood 1995;86(11):4382 PubMed Epub 1995/12/01

36. Steinberg MH, Rosenstock W, Coleman MB, Adams JG, Platica O, Cedeno M, et al. Effects of thalassemia and microcytosis on the hematologic and vasoocclusive severity of sickle cell anemia. Blood. 1984;63(6):1353 PubMed -60. Epub 1984/06/01.

37. Mukherjee MB, Surve R, Tamankar A, Gangakhedkar RR, Ghosh K, Lu CY, et al. The influence of alpha-thalassaemia on the haematological \& clinical expression of sickle cell disease in western India. The Indian Journal of Medical Research. 1998;107:178-81. Epub 1998/05/30.

38. Darbari DS, Onyekwere O, Nouraie M, Minniti CP, Luchtman-Jones L, Rana S, et al. Markers of severe va- so-occlusive painful episode frequency in children and adolescents with sickle cell anemia. The Journal of Pediat rics. 2012;160(2):286-90. Epub 2011/09/06.

39. Kulozik AE, Kar BC, Serjeant GR, Serjeant BE, Weatherall DJ. The molecular basis of alpha thalassemia in India. Its interaction with the sickle cell gene. Blood. 1988;71(2):467-72. Epub 1988/02/01.

40. Olatunji PO, Falusi AG. Persistent hepatomegaly: an index of severity in sickle cell anaemia. East African Medical Journal. 1994;71(11):742-4. Epub 1994/11/01. 41. Kaine WN. Sickle cell anaemia in children in Eastern Nigeria. A detailed analysis of 210 cases. East African Medical Journal. 1982;59(11):742-9. Epub 1982/11/01.

42. Kahirimbanyi JE. Haematological finings in steady state sickle cell anaemia patients [Thesis]: Makerere University 1976

43. Coutinho GA. Iron status in Ugandan sicklers [Msc Physiology]: Makerere University; 1987.

44. Adekile AD, Huisman TH. Level of fetal hemoglobin in children with sickle cell anemia: influence of gender, haplotype and alpha-thalassemia-2 trait. Acta Haematologica. 1993;90(1):34 PubMed -8. Epub 1993/01/01. 45.Ndugwa C, Higgs D, Fisher C, Hambleton I, Mason K, Serjeant BE, et al. Homozygous sickle cell disease in Uganda and Jamaica a comparison of Bantu and Benin haplotypes. The West Indian Medical Journal. 2012;61(7):684-91. Epub 2013/04/30. 